\title{
Development of Android-Based Learning Media for Students on Electrochemistry Materials
}

\author{
$1^{\text {st }}$ Sarip Hidayat ${ }^{1}, 2^{\text {nd }}$ Burhanudin Milama $^{1}, 3^{\text {rd }}$ Buchori Muslim $^{1}$ \\ \{sariphidayat@upi.edu ${ }^{1}$, burhanudin.milama@uinjkt.ac.id ${ }^{1}$, buchorimuslim@uinjkt.ac.id ${ }^{1}$ \} \\ UIN Syarif Hidayatullah, Chemistry Education Study Program, Jakarta, Indonesia ${ }^{1}$
}

\begin{abstract}
This study is aimed at developing android-based learning media on the material of Electrochemistry. This study is conducted through Design and Development model which consist of: (1) planning, (2) design, and (3) development. At development stage, the researcher conduct media testing which is aimed at determining the worthiness of the learning media. The media testing performed are alpha test, beta test I, and beta test II. After that, the effectiveness test is conducted through alpha test to obtain value of $100 \%$ which shows that the media can be used as learning media. The results of on Beta test 1 get the average percentage of $78,4 \%$ with good remarks. While in the Beta test II, the media gets very good remark with the value of $85,16 \%$. Based on the summative evaluation results, it can be concluded that the Android-based media can improve students' competency on electrochemistry materials. This can be seen from the result of ttest which shows that there is a significant difference between control group and experimental group with Sig.(2-tailed) value or $\rho$-value on the value posttest of $0,014<$ 0,05 .
\end{abstract}

Keywords: component; learning media; electrochemistry; android; media development

\section{Introduction}

Indonesia has entered the era of free market within the scope of South East Asian or ASEAN Economic Community (Masyarakat Ekonomi Asean - MEA). That matter makes Indonesia competes with countries in Southeast Asia in all fields. Improving the quality of education is the key to be able to compete. The role of universities as implementors of education can not be separated from efforts to improve the quality of education. Thus, the lectures in universities need to be improved by innovating and making breakthroughs based on science technology and innovation [1].

The progress of technology makes it easy for us to make innovations in the learning process. One of the technologies that can be used is smartphone. Smartphones are devices that have features like computers and mobile devices (phones). Unlike the feature-phone, smartphones have larger storage and local memory such as computers [2]. Most of people use smartphones not just for communicating but also for internet browsing, email, blogging, and games [3]. The recent survey shows that $89,7 \%$ of university students in Indonesia use internet dan $47,6 \%$ of them use mobile devices. As for the 132.7 millions internet users, $25.3 \%$ of them use internet for information updates and 9.2\% for education-related causes [4]. These data shows the low use of smartphones and internet for education or the learning process. 
Goggin revealed that information technology (IT) has made students more computer literate. Increased use of these mobile devices such as mobile phones, iPads, smartphones, tablets and PDAs has become an international phenomenon [5]. Educational institutions must utilize this phenomenon to improve the learning process. One of the way is by using smartphones as learning media based on Mobile Learning (M-Leaning) which can provide opportunities for students to study anywhere and anytime.

Mobile learning is a distant learning and an extension of e-learning applications which has invaded the world with the use of audio, visual, cognitive, cooperative and interactive means via the use of smart and digital electronic devices in an attempt to create a direct, dynamic, ongoing learning environment, i.e. an environment that is not constrained by spatial and temporal boundaries, leading to the elimination of traditional classrooms, routines and imitation [6]. Callaway [7] defines mobile learning as "any sort of learning that happens when the learner is not at a fixed, predetermined location".

The application of mobile learning can provide new experiences in the learning process. Research conducted by Kim, Rueckert, Kim, \& Seo shows that mobile technology has the potential to provide new learning experiences and provide more learning opportunities [8]. Mobile learning can also influence students' learning outcomes. This is in line with the results of research conducted by Elfeky and Masadeh that mobile learning has a significant influence on academic achievement [9].

The identification study on students in the Chemistry Education Study Program of UIN Syarif Hidayatullah shows that most students have smartphone devices and use the internet every day to get information or references for their needs in doing college assignments. Other research shows that in basic chemistry learning, the use of online media can improve students' ability to do assignments as much as $66.67 \%$ [10]. The results of this identification and research support the author to develop an android-based learning media that is interesting and enables students to learn easier.

De Jong and Treagust mentioned that electrochemistry material is loaded with abstract concepts such as the process of releasing and receiving electrons that cannot be seen with the eye. Thus, learning media is needed to facilitate students in the process of learning electrochemistry material. Based on that, the authors conducted the development of Androidbased learning media for students on electrochemistry material.

\section{Methods}

The development model used in this study is the Design and Development model. This model is usually used to produce simple computer-based media products [11]. This means that this model can also be used to develop Android-based media. This model consists of three stages, namely (1) Planning, (2) Design, (3) Development, and (4) Test of product effectiveness.

Development and Research was carried out in the Chemical Education Study Program of Syarif Hidayatullah State Islamic University.

The object of this research is android-based learning media on electrochemistry material. While the research subjects include: (1) 5 lecturers as experts consisting of 3 lecturers to validate the product and 2 lecturers to validate the research instrument in the form of questionnaires, (2) 31 students of Batch 2015 in Chemistry Education Program of UIN Syarif 
Hidayatullah as respondents in the beta test, and (3) 30 students of Batch 2016 in Chemistry Education Program of UIN Syarif Hidayatullah as samples at the product testing stage.

Data collection procedure used to assess the feasibility of learning media is through alpha test, beta test, and learning outcomes test. Alpha test is done to get data about product assessment that has been developed by experts. The alpha test instrument model follows an evaluation sheet from Alessi \& Trollip. While the beta test is a student assessment of the media. The instrument used is a closed question based on Walker \& Hess criteria and uses a Likert scale. The analysis of learning outcomes is aimed at knowing the success of Androidbased chemistry learning media on improving student learning competencies.

\section{Result and Discussion}

\subsection{Planning Stage}

This planning stage is the initial stage to develop learning media. In this stage, researchers begin by determining the purpose of making media and preparing some aspects that are used to begin the development of the media.

The development begins with defining the scope of the material to be presented in the learning media. The scope of the material presented is based on the Basic Competencies of Learning Outcomes of IQF on the element of knowledge (KD2), i.e. describing electrochemistry. The material scope is to explain the concept of galvanic cells, calculate standard reduction potential, connect galvanic cells with changes in free energy gibbs, equilibrium constants, and Nernst equations, explain the concept of electrolysis cells, connect the quantitative aspects of the current supplied with the products formed.

After that, the students' characteristics are analyzed. This is done so that the results of the development are as expected and in line with the opinion of Frey \& Sulton [12] that if the three components of the objectives, objectives, and audience analysis are carried out, it will ensure that the products developed will meet the expected results. Based on the identification results by using a questionnaire, there are some descriptions of the characteristics of 2017 Chemistry Education Program UIN Syarif Hidayatullah level one students:

a. All students have a smartphone.

b. Students rarely use smartphones during lectures.

c. Students often use smartphones to browse lecture materials outside of class or when studying independently.

d. The lack of learning media applications makes students lazy to use smartphones as a medium for learning.

e. Most students are very enthusiastic if the smartphone device is installed in the learning media application.

The next step is to find and create images for media and audio display for the media backsound to make it interesting. In addition, animated images and videos are used as visual aids in the delivery of material to the media. Visual aids are used to arise students' interests and to help explain concepts easily [13]. The source material used was the three basic chemistry books of the university written by Raymond Chang, Keenan, and Ralph Petrucci. The three books were chosen because they are books that are often used for reference by students and lecturers in the Chemistry Education Program of UIN Syarif Hidayatullah. Whereas the selected development resources are tailored to the needs. CorelDraw X7 was chosen to help develop the appearance of the media. Whereas Android Studio is used to 
develop learning media in the form of applications. Google firebase is also used as a place to store material data that will be displayed on the media.

\subsection{Design Stage}

Based on the identification of basic competencies and indicators of basic chemistry courses, the sub-courses that will be explained in the media are: electrochemistry and electrochemistry cells, voltaic or galvanic cells, cell notation, cell potential, voltaic series, spontaneity of redox reactions, thermodynamic equilibrium constants of standard cell potential, influence of concentration on cell potential, cell concentration, cell electrolysis, reaction on electrolysis cells and quantitative aspects of electrolysis cells.

After that, a concept analysis is carried out to find out the basics that will be presented with reference to the competencies and indicators that have been set. Concept analysis is conducted by identifying the characteristics of the concept, which include; concept labels, concept definitions, concept types, concept attributes, concept hierarchies, examples and nonexamples [14]. In addition, a task analysis is also carried out to get an overview of the steps taken by students when conducting learning using learning media to understand the concept of electrochemistry.

Text material and questions on the media are compiled from various relevant sources. Presentation of the material is also equipped with visual video. Visual video can help to clarify abstract materials [15]. Practice questions are presented in the quiz menu. The questions given have varying cognitive levels. In the quiz menu there is also feedback so students can measure and know their level of mastery of electrochemistry material.

\subsection{Development Stage}

At the development stage, media production, evaluation and revision are carried out. Media production is carried out according to the design that has been made. Media revisions are carried out based on the results of media evaluation to get improvements. The result of advisability trial on Android based learning media is obtained from alpha test, beta test, and analysis of learning outcomes.

Alpha test produces an average assessment of material and media experts in the first alpha test resulting in an assessment of $80.25 \%$. After a revision of the changes, the second alpha test was carried out and resulted in an average rating of $82.22 \%$ to be revised. The third alpha test obtained $100 \%$ result which means the media can be used.

The next test is beta test, which is conducted by testing the learning media to the 2015 Chemistry Education students to be given an assessment. At this stage, the assessment results are obtained. The assessment results of the students determine the feasibility of the developed learning media, while the data in the form of suggestions and comments are used as material for the final revision of the product. In order to produce better learning media, Beta tests were conducted twice.

Table 1. Beta Test Result

\begin{tabular}{|c|c|c|c|}
\hline Aspect & Indicator & $\begin{array}{c}\text { Beta test I } \\
(\%)\end{array}$ & $\begin{array}{c}\text { Beta test II } \\
(\%)\end{array}$ \\
\hline \multirow{3}{*}{$\begin{array}{c}\text { Quality of } \\
\text { content and } \\
\text { purpose }\end{array}$} & Accuracy & 83.87 & 83.23 \\
\cline { 2 - 4 } & Interests & 79.35 & 81.94 \\
\cline { 2 - 4 } & Completeness & 76.13 & 83.23 \\
\cline { 2 - 4 } & $\begin{array}{c}\text { Interest and } \\
\text { attention }\end{array}$ & 70.32 & 85.16 \\
\hline
\end{tabular}




\begin{tabular}{|l|l|l|l|}
\hline \multirow{4}{*}{$\begin{array}{l}\text { Quality of } \\
\text { learning }\end{array}$} & $\begin{array}{l}\text { Provide learning } \\
\text { opportunities }\end{array}$ & 81.94 & 89.68 \\
\cline { 2 - 4 } & $\begin{array}{l}\text { Provide assistance } \\
\text { for learning }\end{array}$ & 80 & 84.52 \\
\cline { 2 - 4 } & Motivating quality & 76.77 & 84.52 \\
\cline { 2 - 4 } & $\begin{array}{l}\text { Flexibility of } \\
\text { learning }\end{array}$ & 84.52 & 91.61 \\
\cline { 2 - 4 } & $\begin{array}{l}\text { Relationship with } \\
\text { other learning } \\
\text { programs }\end{array}$ & 82.58 & 85.81 \\
\cline { 2 - 4 } & $\begin{array}{l}\text { Social quality of } \\
\text { learning interaction }\end{array}$ & 70.32 & 80 \\
\cline { 2 - 4 } & $\begin{array}{l}\text { Test quality and } \\
\text { assessment }\end{array}$ & 80.65 & 85.81 \\
\cline { 2 - 4 } & $\begin{array}{l}\text { Can have an impact } \\
\text { on students }\end{array}$ & 76.12 & 86.45 \\
\cline { 2 - 4 } & $\begin{array}{l}\text { Can have an impact } \\
\text { on teachers and } \\
\text { learning }\end{array}$ & 76.77 & 83.87 \\
\hline Technical & Legibility & 81.94 & 88.39 \\
\cline { 2 - 4 } Quality & $\begin{array}{l}\text { Easy to use } \\
\text { Display quality or } \\
\text { impressions }\end{array}$ & 80.65 & 89.68 \\
\cline { 2 - 4 } & $\begin{array}{l}\text { Quality of handling } \\
\text { answers }\end{array}$ & 75.48 & 84.52 \\
\cline { 2 - 4 } & $\begin{array}{l}\text { Quality of } \\
\text { documentation }\end{array}$ & 78.06 & 84.52 \\
\hline Average & 78.28 & 85.38 \\
\hline
\end{tabular}

Table 1 shows that media based android is very good to be used in learning process.

Indicators with the highest percentage of aspects of content quality and purpose are interests and attention that get a percentage of $85.16 \%$. The table shows that the development of chemistry lecture learning media application is able to attract students' interest and attention. This result is in line with the results of Hanafi and Samsudin's research that using the android application boosts students' motivation because it is interactive and simple [16].

Indicators that also get a large percentage in the aspects of content and purpose quality are the completeness of the contents of the learning media with a value of $83.23 \%$. It shows that the content of the material and other features in the media are complete so it helps students in studying electrochemistry. This is in line with the theory which states that learning media can facilitate the mastery of a student's basic skills and help understand abstract concepts [17].

In the aspect of learning quality, the indicator that has the highest percentage is the learning flexibility, which has a percentage of $91.61 \%$. This value is obtained because the Android-based learning media is able to implement mobile learning so that learning becomes flexible. Mobile learning that involves smartphone devices can provide learning that can be done anytime and anywhere [18].

Learning opportunity indicators also have the highest percentage with a value of $89.68 \%$ and have a very good category. These results prove that the nature of learning media on Android-based learning media paired on smartphone devices is able to provide learning opportunities to students anywhere and anytime. This is reinforced by the opinion of Mehdipour and Zarehkafi that mobile learning will provide learning opportunities anywhere 
and anytime [19]. Park's research also shows that mobile devices will greatly help students learn independently [20].

The third aspect assessed from the Chemistry Lecture learning media is technical quality. The ease indicator gets the highest percentage value of $89.68 \%$. Mobile devices are easier to use and are not a hassle. The major advantage of using mobile device based service is that users need not procure computer equipments [21]. In addition, the indicator that has a large percentage value is the quality of legibility, i.e. $88.39 \%$. This means that the readability is very good. This shows that the type and size of the fonts are easy to read.

\subsection{Effectiveness Test Stage}

After the entire series of development and revision is complete, the study proceed with summative evaluation or effectiveness testing. Sumative evaluation is conducted to determine the effectiveness of the media. The evaluation was conducted by measuring the students' skills or knowledge about the material taught before and after learning [12].

Test of product effectiveness is carried out in two groups, i.e. control group and the experimental group. The experimental group was given an Android-based learning media namely the chemistry lecture application to be used as their independent learning media. Meanwhile, control group study without chemistry lecture application. The result of pretest and posttest was tested using t-test trial to know the effectiveness of learning media based on android. The t-test was carried out to study the differences in the average criterion variables of the two groups or which could be classified into two groups. The hypothesis used in this t-test is:

$\mathrm{H}_{0}=$ There is no difference in the average value of learning outcomes between the experimental group and the control group.

$\mathrm{H}_{1}=$ There is a difference in the average value of learning outcomes between the experimental group and the control group.

Table 2. Data Result Group Statistics Independent Sample Test

\begin{tabular}{|l|l|l|l|l|l|}
\hline & Group & $\mathrm{N}$ & Mean & $\begin{array}{l}\text { Std. } \\
\text { Deviation }\end{array}$ & $\begin{array}{l}\text { Std. } \\
\text { Mean }\end{array}$ \\
\hline \multirow{2}{*}{ Pretest } & Control & 16 & 32.81 & 6.047 & 1.512 \\
\cline { 2 - 6 } & Experiment & 16 & 30.94 & 6.115 & 1.529 \\
\hline \multirow{2}{*}{ Posttest } & Control & 16 & 80.62 & 5.123 & 1.280 \\
\cline { 2 - 6 } & Experiment & 16 & 85.94 & 6.382 & 1.595 \\
\hline
\end{tabular}

Table 2 shows that the average value of the pre-test in the control class is greater than the value in the experimental class. As for the average post-test value, the experimental class that uses Android-based learning media has a higher average value than the control class that does not use media.

Table 3. Data Result Independent Sample Test

\begin{tabular}{|l|l|l|l|}
\hline Group & df & Sig. (2-tailed) & $\alpha$ \\
\hline Pretest & 30 & 0,390 & 0,05 \\
\hline Posttest & 30 & 0,014 & 0,05 \\
\hline
\end{tabular}

Based on the Independent sample t-test on the pretest value of both groups, the value of Sig. (2-tailed) is greater than $\alpha=0.05$. it's found that $\mathrm{H}_{0}$ is accepted and $\mathrm{H}_{1}$ is rejected because 
$\rho>\alpha$. The table shows that there is no difference in the average between the pretest value of the control group and the experimental group. Whereas in the analysis of posttest results it is known that Sig. (2-tailed) is smaller than $\alpha=0.05$. Thus $\mathrm{H}_{0}$ is rejected and $\mathrm{H}_{1}$ is accepted because $\rho<\alpha$. This means that there is a difference in the average between the posttest value of the control group and the experimental group.

There are two factors that influence learning outcomes, i.e. intrinsic factors and extrinsic factors. One of the extrinsic factors that influence learning outcomes is the use of learning media. The use of Android-based learning media makes it easy to access learning so students can get more material. The mobile self-regulated learning approach significantly enhanced students' learning outcomes and self-regulated learning skills [22]. This is also in line with the research of De-Marcos et al, who designed an application for mobile phones and the results showed an improvement in terms of student learning achievement, especially among young students [23].

\section{Conclusion}

Based on the validation results of learning media from several validators in the alpha test, the android-based learning media are categorized as very good and can be used. Whereas from the results of the response test in the second beta test by students, the media are categorized as very good with an average percentage of $85.38 \%$. Thus, Android-based learning media on electrochemistry material can be used as a learning medium for students. Effectiveness testing using the t-test posttest results obtained Sig. (2-tailed) value of 0.422 , which is smaller than $\alpha$ $=0.05$, meaning that $\mathrm{H}_{0}$ is rejected and $\mathrm{H}_{1}$ is accepted. So, it can be concluded that the learning process using Android-based learning media is effective to improve learning outcomes, because there are significant differences in learning outcomes between the experimental group and the control group.

Acknowledgements. This paper in conjuction with the 21st International Conference On Electrical Machines and System (ICEMS) 2018, Jeju, Korea

\section{References}

[1] A. Rosyid, "Technological Pedagogical Content Knowledge: Sebuah Kerangka Pengetahuan Bagi Guru Indonesia di Era MEA,”Semin. Nas. Inov. Pendidik., 2016.

[2] K. Lusekelo and M. Gervas, "A Review on the Impact of Smartphones on Academic Performance of Students in Higher Learning Institutions in Tanzania," Multidiscip. Eng. Sci. Technol., 2015.

[3] M. A. Osman, A. Z. Talib, and Z. A. Sanusi, "A Study of the Trend of Smartphone and its Usage Behavior in Malaysia," Int. J. New Comput. Archit. Their Appl., 2012.

[4] Y. H. Widiartanto, "2016, Pengguna Internet di Indonesia Capai 132 Juta," Kompas.com. 2016.

[5] S. Bidin and A. A. Ziden, "Adoption and Application of Mobile Learning in the Education Industry," Procedia - Soc. Behav. Sci., 2013.

[6] T. A. Saleem, "Mobile learning technology: A new step in e-learning," J. Theor. Appl. Inf. Technol., 2011.

[7] D. Popescu, I. Chivu, A. Ciocârlan-Chitucea, D. O. Popescu, and C. Georgel, "The learning 
organization challenges within the SMEs tourism field of activity," in Procedia - Social and Behavioral Sciences, 2011.

[8] D. Kim, D. Rueckert, D.-J. Kim, and D. Seo, "Students' Perceptions and Experiences of Mobile Learning," Lang. Learn. Technol., 2012.

[9] A. I. M. Elfeky and T. S. Yakoub Masadeh, "The Effect of Mobile Learning on Students' Achievement and Conversational Skills," Int. J. High. Educ., 2016.

[10] A. B. Flynn, "Development of an online, postclass question method and its integration with teaching strategies," J. Chem. Educ., 2012.

[11] S. Alessi and S. Trollip, "Multimedia for learning," Methods Dev., 2001.

[12] B. A. Frey and J. M. Sutton, "A Model for Developing Multimedia Learning Projects," MERLOT J. Online Learn. Teach., 2010.

[13] N. et al. Iqbal, "Impact of Visual Aids in Enhancing the Learning Process Case Research: District Dera Ghazi Khan.," J. Educ. Pract., 2015.

[14] J. D. Herron, L. L. Cantu, R. Ward, and V. Srinivasan, "Problems associated with concept analysis," Sci. Educ., 1977.

[15] G. Chittleborough, "Learning How to Teach Chemistry with Technology: Pre-Service Teachers' Experiences with Integrating Technology into Their Learning and Teaching," $J$. Sci. Teacher Educ., 2014.

[16] H. F. Hanafi and K. Samsudin, "Mobile Learning Environment System (MLES): The Case of Android-based Learning Application on Undergraduates' Learning," IJACSA) Int. J. Adv. Comput. Sci. Appl., 2012.

[17] S. Malik and A. Agarwal, "Use of Multimedia as a New Educational Technology Tool-A Study," Int. J. Inf. Educ. Technol., 2012.

[18] N. Y. Asabere, "Benefits and Challenges of Mobile Learning Implementation: Story of Developing Nations,” Int. J. Comput. Appl. (0975 - 8887), 2013.

[19] Z. H. Mehdipour Yousef, "Mobile Learning for Education: Benefits and Challenges," Int. J. Comput. Eng. Res., 2013.

[20] Y. Park, "A pedagogical framework for mobile learning: Categorizing educational applications of mobile technologies into four types," Int. Rev. Res. Open Distance Learn., 2011.

[21] R. K. Bhardwaj and P. K. Jain, "Research trends in mobile learning: A global perspective," Collnet J. Sci. Inf. Manag., 2015.

[22] K. B. Butzler, "The Synergistic Effects of Self-Regulation Tools and the Flipped Classroom," Comput. Sch., 2016.

[23] W. H. Wu, Y. C. Jim Wu, C. Y. Chen, H. Y. Kao, C. H. Lin, and S. H. Huang, "Review of trends from mobile learning studies: A meta-analysis," Computers and Education. 2012. 